Iwona MASSAKA

Uniwersytet Mikołaja Kopernika, Toruń

\title{
Polityczna funkcja muzyki. Antyteza estetyki autonomii dzieła muzycznego
}

Czy tworzenie i odtwarzanie dzieła muzycznego jest wyłącznie aktem
swobodnej ekspresji twórcy, a jego jedynym celem jest doznanie i do-
starczenie wrażeń estetycznych? Czy sztuka powstająca bez udziału
słowa i obrazu, odbierana bez pośrednictwa swego zapisu ${ }^{1}$ może zawierać
jednoznaczny komunikat, sugestię lub nakaz o powszechnym zasięgu?
Czy muzykę, w tym muzykę instrumentalną, można z powodzeniem sto-
sować jako narzędzie powszechnego oddziaływania, wywoływania po-
żądanych reakcji społecznych, manipulacji?
Aby zbliżyć się do odpowiedzi na te pytania trzeba - z jednej strony-
zbadać sztukę muzyczną z punktu widzenia roli, jaką spełnia w różnych
społeczeństwach, traktowanych jako całość, jak również w poszczegól-
nych grupach społecznych ${ }^{2}$ - z drugiej zaś - rozpatrywać jąjako zjawisko
polityczne samo w sobie. Polityczna natura muzyki - szczególnie muzyki
polifonicznej - wiąże się z jej pochodzeniem. Powstała ze zbiorowych
praktyk kultowych i tanecznych jako narzędzie integracji i oddziaływania.
Ta właśnie geneza historyczna określa charakter każdej muzyki, również
takiej, którą wykonuje się solo. Jeśli bowiem nawet nie jest wykonywana

1 Nie należy utożsamiać dzieła muzycznego z jego zapisem nutowym. Partytura jest jedynie jego umownym i niejednoznacznym przyporządkowaniem. Pod tym względem dzieło muzyczne różni się zasadniczo od dzieła literackiego, gdzie język wchodzi w skład dzieła, wręcz warunkuje jego percepcję. Muzyka może być odbierana bez pośrednictwa swego zapisu, podczas jej słuchania w zasadzie nie pamięta się o nim. Zob.: L Polony, Polski kształt sporu o istote muzyki, Kraków 1991, s. 254.

2 Społeczne cele muzyki są przedmiotem badań socjologii muzyki i etnomuzykologii. Brane są także niekiedy pod uwagę przez historyków muzyki i muzykologów. Zob np.: I. Supičič, Wstęp do socjologii muzyki, Warszawa 1969; A. Golèa, La musique dans la sociètè europèenne depuis le Moyen Age jusqu'a nos jours, Paris 1960; W. Mellers, Music and society, England and the European Tradition, London 1950; T. Adorno, Filozofia nowej muzyki, Warszawa 1974. 
zbiorowo, z całą pewnością przeznaczona została do zbiorowego (choć niekoniecznie w tym samym czasie i miejscu) słuchania. Kompozytor tworzy, a muzyk odtwarza muzykę nie dla siebie, lecz z zamiarem poruszenia publiczności, oddziałania na zbiorowość, zintegrowania jej podczas wspólnego doznania. „Muzyka jest pompą do nadmuchiwania duszy - jak trafnie zauważył Milan Kundera. - Przerośnięte dusze przemienione w ogromne balony szybują pod sufit sali koncertowej i tłocząc się okropnie wpadają na siebie"3. Muzyka może obiektywizować się jedynie poprzez oddziaływanie, tym silniej się manifestuje im szersze zatacza kręgi. Muzyka mówi „my” nawet wtedy, gdy żyje tylko w wyobraźni kompozytora i poza nim do nikogo żywego nie dociera ${ }^{4}$.

Muzyka od początku swego istnienia pełniła w sferze publicznej oprócz estetycznej funkcji „upiększania życia” - funkcje pozaestetyczne. Funkcja uświetniająca okoliczności ważne dla poszczególnych grup społecznych oraz sytuacje o znaczeniu narodowym i międzynarodowym łączy się na ogół z funkcją pobudzającą i integracyjną. Pomiędzy uczestnikami uroczystości tworzą się określone typy więzi społecznej, narodowej czy ogólnoludzkiej. Wspólne skandowanie i klaskanie na wiecach, zebraniach partyjnych lub imprezach sportowych, maszerowanie w pochodach i na defiladach $\mathrm{z}$ towarzyszeniem orkiestry lub jedynie w rytm kroków, tańce podczas zabaw weselnych, imprez towarzyskich o charakterze służbowym i prywatnym, śpiewanie pieśni podczas obrzędów religijnych, manifestacji, procesji, akademii, zabaw i pogrzebów, a także rytualne zawodzenie żałobników ${ }^{5}$, stymuluje określony i pożądany rodzaj emocji i refleksji, pomaga umieścić swój światopogląd w obrębie światopoglądu grupy, utożsamić się z nią, wywołać uczucie przynależności i lojalności. Muzyka jest jednym z najskuteczniejszych narzędzi ideologicznych, budzi instynkt zbiorowy, solidaryzm, entuzjazm, jednomyślną wolę. Ideologie głoszone przez wyznawców wszystkich religii nie byłyby nośne bez muzyki ${ }^{6}$ o rodowodzie sakralnym lub profanicznym, aczkol-

3 M. Kundera, Nieśmiertelność, Warszawa 1995, s. 233.

${ }^{4}$ Por. T. Adorno, Filozofia nowej muzyki ..., s. 50.

5 Rytualny płacz podczas pogrzebu jest zjawiskiem charakterystycznym w kulturze niektórych narodów afrykańskich oraz w kulturze arabskiej, kurdyjskiej i judaistycznej.

${ }^{6}$ Muzyka nie tylko towarzyszy obrzędom religijnym, lecz także poprzedza właściwe obrzędy, pomagając zgrupować ich uczestników. Jest nią rytualne bicie w bębny i dzwony, dźwięk kołatek i młynków, a także nawoływanie muezzina do modlitwy w kulturze muzułmańskiej. 
wiek możliwym do wykorzystania na gruncie religijnym. Ideologie narodowe wyrażają się w hymnach, pieśniach patriotycznych, pieśniach rewolucyjnych, pieśniach gniewu narodowego, operach narodowych itp. Uniwersalna i ponadnarodowa ideologia totalnego konsumpcjonizmu ${ }^{7}$ posiłkuje się homogeniczną mieszaniną muzyczną różnych epok i kultur.

Utwór muzyczny wykorzystywany jest zwykle bez intencji autora. Jest produktem jego pracy twórczej, który od chwili skomponowania rozpoczyna swoje, odrębne od osoby twórcy, istnienie. Trwa ono nawet po śmierci autora - utwór zatem nie jest częścią jego życia psychicznego, choć nosi cechy osobowości i temperamentu twórcy. Jednak nawet to staje się wątpliwe w świetle teorii Zygmunta Freuda, która zgłasza wątpliwość w jakikolwiek związek pomiędzy siłą twórczą i intencją kompozytora a kształtem jego utworu. „Dzieło wzrasta jak chce - twierdzi Freud - niekiedy staje wobec swego autora jako utwór niezależny lub wręcz obcy"8. Wątpliwe staje się zatem czy utwór muzyczny może w jakiś sposób odzwierciedlać światopogląd jego twórcy, tym bardziej nie ma powodu sądzić by mógł być odbiciem jakiegoś innego światopoglądu. Użycie utworu muzycznego jako narzędzia ideologicznego, a tym samym zasugerowanie związku tego utworu z konkretną ideologią, często rozciąga tę sugestię na osobę twórcy, wiążąc już nie tylko utwór, lecz jego samego z określoną ideologią. Przeciwko tej niesprawiedliwej praktyce zaprotestowało w latach 90-tych wielu polskich i rosyjskich kompozytorów, zwłaszcza tych, których twórczość uważano w PRL i ZSRR za programową: Andrzej Panufnik, Grażyna Bacewicz, Tadeusz Baird, Witold Lutosławski, Dymitr Szostakowicz, Igor Strawiński i Aleksander Gauk twórca baletów i dyrygent najlepszych orkiestr radzieckich ${ }^{9}$. Oczywiście, ich dementi w dużym stopniu było próbą rehabilitacji, drogą wyparcia się oczywistych związków z partią komunistyczną, lecz samo zwrócenie uwagi na powszechne i błędne odczytywanie związku między ideologią, dziełem muzycznym i jego twórcą było słuszne i interesujące.

7 Zob np. R. Paradowski, Etos obywatelski i kultura, „Społeczeństwo Otwarte” 1996, nr 11; W. Paradowska, R. Paradowski, Dominacja i wolność w kulturze, w: Kulturowe instrumentarium panowania, pod red. R. Paradowskiego, P. Załęckiego, Toruń 2002.

8 Zob. Z. Freud, Człowiek, religia, kultura, Warszawa 1967, s. 202.

9 Zob.: S. Wołkow, Świadectwo. Wspomnienia Dymitra Szostakowicza, Warszawa 1989; K. Meyer, Szostakowicz, Kraków 1986. 
Ten sam utwór muzyczny może być wykorzystywany do wyrażenia sprzecznych ze sobą ideologii. Wiadomo, że muzyka do hymnu hitlerowskiego Hortwessel Lied została przejęta przez hitlerowców od komunistów. Do muzyki pieśni rewolucyjnej dodano tekst faszystowski. Znany był na początku lat 80-tych wypadek w Parlamencie Francuskim kiedy to komuniści i przedstawiciele prawicy śpiewali Marsylianke przeciwko sobie. Tutaj nie tylko muzyka, lecz i słowa nie uległy żadnej zmianie, ale Marsylianka co innego znaczyła w ustach komunistów i co innego w ustach posłów prawicy. Funkcja ideologiczna nie jest żadnej muzyce (w przeciwieństwie do słów) przypisana na stałe. Może ulegać zmianom w zależności od tego, w obręb jakiej ideologii zostanie wciągnięta i z nią utożsamiona. Msza wykonywana w kościele w czasie nabożeństwa pełni inne funkcje ideologiczne niż ta sama msza wykonywana w sali filharmonii ${ }^{10}$.

Fakt, iż muzyka wspomaga ideologie, będąc instrumentem integracji i bodźcem do działania w myśl programów politycznych nie budzi wątpliwości. Kwestią dyskusyjną pozostaje zasadność odczytywania utworu muzycznego jako komunikatu ideologicznego czy w ogóle jakiegokolwiek komunikatu. Chodzi tu zwłaszcza o utwory wyłącznie melodyczne $\mathrm{i}$ instrumentalne, nie zawierające tekstu. Spór o to, czy tego rodzaju dzieło muzyczne może być odczytywane inaczej niż jako czysta forma - kompozycja dźwięków i wartości rytmicznych - nie został rozstrzygnięty: jest stale obecny w estetyce muzycznej. Podstawowa kontrowersja pomiędzy przedstawicielami stanowisk, które określić można jako ekspresjonistyczne i formalistyczne wyrażana jest poprzez charakterystykę utworów muzycznych. Zdaniem „ekspresjonistów” mają one swój „wyraz”, są „ekspresyjne” czy też „wyrażają” różnego rodzaju stany rzeczy. Formy muzyczne rozwijają się, pozwalając budować napięcie i je rozładowywać. Trwa to - według nich - dostatecznie długo by wywoływać silne emocje. Zdaniem „formalistów” utwory muzyczne są wyłącznie lub przede wszystkim pewnego typu konstrukcjami, których percepcja wymaga zaangażowania intelektualnego ${ }^{11}$. Zwolennicy „estetyki treści” i „estetyki formy" różnie oceniają stosunek muzyki do rzeczywistości pozamuzycznej. Pierwsi twierdzą, że oprócz abstrakcyjnych i intelektualnych znaczeń

10 Zob.: P. Beylin, Muzyka i życie, w: Ospołecznych problemach muzyki, M. Demska-Trębaczowa, Warszawa 1984, s. 41.

11 Zob.: G. Banaszak, Formy współczesnej kultury muzycznej, Warszawa 1991, s. 83 . 
muzyka komunikuje też znaczenia, które w jakiś sposób odnoszą się do pozamuzycznego świata pojęć, czynności, stanów intelektualnych i właściwości, może wyrażać odgłosy natury, ruch, skojarzenie krajoznawcze i panoramiczne, przeżycia psychiczne, przebiegi emocjonalne, sytuacje społeczne i myśli o różnych aspektach społecznych i politycznych, drudzy zaś utrzymują, że znaczenie muzyczne tkwi wyłącznie w obrębie samego dzieła, w spostrzeganiu związków występujących w muzycznym dziele sztuki ${ }^{12}$. Dla „formalistów” muzyka może znaczyć wyłącznie samą siebie, gdyż zaciera się w niej typowa dla innych systemów komunikacyjnych odrębność elementu znaczącego i znaczonego - znaczenie dźwięku jest identyczne z nim samym. Spór polskich „formalistów” i „ekspresjonistów” nabrał szczególnej mocy w latach 1948-1949. W poszczególnych środowiskach twórczych odbyła się wówczas seria narad, na których określono zasady socrealizmu. W sierpniu 1949 w Łagowie Lubuskim miała miejsce konferencja kompozytorów, na której usiłowano arbitralnie rozstrzygnąć kwestię zawartości dzieła muzycznego i utylitaryzmu muzyki. Do rozstrzygnięcia nie doszło, wręcz przeciwnie - dyskusja dotycząca ontologii muzyki weszła w kolejną fazę, utrwalając w środowisku muzykologicznym i kompozytorskim podział na „formalistów” i „realistów”, jak nazywano po 1949 roku głosicieli poglądu, iż muzyka stanowi przede wszystkim „nadbudowę ideologiczną [...] odzwierciedlającą obiektywną rzeczywistość społeczno-historyczną"13. Wśród obrońców muzyki jako czystej formy wyróżnili się zwłaszcza Stefan Kisielewski i Witold Lutosławski ${ }^{14}$. Wskazywali na asemantyczność i niejednoznaczność muzyki. Według nich muzyka instrumentalna nie zawiera konkretnie określonej treści (treścią nie jest dla nich ani zawartość obrazowo - skojarzeniowa, ani zawartość emocjonalna) - gdyby tak było wszyscy słuchacze odczytywaliby ją w identyczny sposób ${ }^{15}$. Adwersarze Kisielewskiego - muzykolodzy Zofia Lissa, Józef Chomiński i Stefania Łobaczewska oraz minister kultury Włodzimierz Sokorski zarzucili „formalistom”, nieprzystający do obowiązującej ideologii hiperidealizm estetyczny, który nikomu nie jest potrzebny i nikomu nie służy. Zarzut był niesłuszny - „formaliści” nie zrezygnowali ze służby społecznej, odwrotnie - uważali, że istnienie czy-

12 Por.: L. Meyer, Emocja i znaczenie w muzyce, Kraków 1974, s. 11.

13 L. Polony, Polski ksztalt sporu ..., s. 284.

14 Zob.: W. Lutosławski, Myśli o percepcji muzyki, w: O społecznych problemach ..., M. Demska-Trębaczowa, s. 139.

15 Zob.: S. Kisielewski, Z muzykq przez lata, Kraków 1957, s. 25. 
stej sztuki muzycznej jest konieczną odpowiedzią na jedną z najgłębszych społecznych potrzeb. Nie postulowali sztuki dla sztuki, lecz chcieli wygospodarować przestrzeń dla specyficznej twórczości, którą uważali zarazem za treść i formę, przestrzeń - według nich - bardzo społecznie pożądaną. Zwolennikom estetyki normatywnej trudno było dowieść, że muzyka w sposób bezpośredni komunikuje i oznacza - jak literatura, film czy teatr - lub przedstawia - jak malarstwo - rzeczywistość społeczną i polityczną, że może zawierać i emitować treść ideologiczną. Trudność tę usiłowano ominąć, umniejszając wartość muzyki czysto instrumentalnej i w ogóle abstrakcjonizmu w sztuce ${ }^{16}$, a także odwracając uwagę od problemu semantyczności dzieła muzycznego i kierując się w stronę zagadnienia humanizmu wyrażanego w muzyce. Dokonano trywialnego rozróżnienia na „antyhumanistyczną, abstrakcyjno-formalną muzykę schyłkowego okresu imperializmu i humanistyczną, pojęciowo-emocjonalną, sugestywną w odbiorczych środkach wyrazu nowoczesną muzykę epoki socjalizmu""17. Myśl ludzka i ludzkie uczucia nie mogą-zdaniem „realistów” - wyrażać się za pośrednictwem czystej formy. Powstał tym samym podział na sztukę muzyczną humanistyczną - wyrażającą określone treści i niehumanistyczną - wyrażającą samą siebie czy - z punktu widzenia estetyków-normatywistów - nie wyrażającą niczego, bezwartościowa $^{18}$. W ten sposób dyskusja na temat ontologicznej istoty muzyki i jej immanentnych właściwości komunikacyjnych zepchnięta została w ślepą uliczkę. Kisielewskiego - w trakcie dowodu na humanitaryzm muzyki $^{19}$ - także ogarnęła wątpliwość czy muzyka wyraża i odzwierciedla coś innego niż tylko samą siebie. Początkowo twierdził, że muzyka jako

16 Por.: N. Chruszczow, Wysoka ideowość i mistrzostwo artystyczne wielkq siła radzieckiej literatury i sztuki. Przemówienie na spotkaniu przywódców partii i rzqdu $z$ działaczami literatury i sztuki 8 marca 1963, „Kraj Rad”, wydanie specjalne, Warszawa 1963, s. 6.

17 W. Sokorski, Ku realizmowi socjalistycznemu w muzyce, „Ruch Muzyczny” 1949, nr $14(92)$, s. 3.

18 Zarzut antyhumanitaryzmu skierowany w stronę muzyki został sformułowany m.in. w powieści Józefa Weyssendorfa Syn Marnotrawny. Porte-parole autora wygłasza tam filipikę na temat muzyki jako sztuki obojętnej na konflikty moralne i światopoglądowe, dostarczającej przyjemności zmysłowej zarówno katom, jak i ich ofiarom (jak wiadomo, do najbardziej muzykalnych narodów należą Niemcy i Żydzi, szczególnie Żydzi pochodzenia słowiańskiego), sztuki w dodatku mało przydatnej, bo hermetycznej i trudnej.

19 S. Kisielewski, Czy muzyka jest niehumanistyczna, „Forum Musicum” 1957, nr 1. 
forma treści nie wyraża lub - inaczej sprawę ujmując - że treścią formy muzycznej jest właśnie owa forma. Po zjeździe w Łagowie Lubuskim, starając się odeprzeć zarzut bezużyteczności czystej formy, przeszedł na pozycję przeciwnika stwierdziwszy, iż abstrakcyjna forma wyraża wartości humanistyczne, można w niej zawrzeć uniwersalne przesłania i ideały, każdą treść myślową czy uczuciową. Zatem - przyznał - forma muzyczna komunikuje treści dotyczące rzeczywistości pozamuzycznej, choć komunikat ten nie jest tak czytelny, łatwy do myślowego zdefiniowania i jednoznaczny jak komunikat słowny czy przekazany za pomocą obrazu. Jest za to bardziej trwały i uniwersalny niż komunikat nadany z pomocą medium mniej abstrakcyjnego. Spór o semantyczność i asemantyczność dzieła muzycznego w kulminacyjnym momencie dotyczył możliwości wykorzystania formy muzycznej jako instrumentu nadawania i utrwalania określonej treści ideologicznej. Ugrzązł on pomiędzy formalistycznym dowodem na to, iż każdy instrumentalny utwór muzyczny jest bezradnym formalnym niemową i normatywistycznym założeniem, iż dowolna treść ideologiczna może być wbudowana w strukturę muzyczną w momencie powstawania kompozycji. Tymczasem mógłby znaleźć rozwiązanie w konkluzji, że muzyka jest znakomitym środkiem propagandowym, bez względu na to czy powstała jako czysta forma do której włożono, nieraz kilkakrotnie, różne treści ideologiczne (nawet „formaliści” przecież w końcu uznali, że wypełnienie treścią formy muzycznej jest możliwe ${ }^{20}$ ), czy też od razu powstała jako określony komunikat. Rzecz w tym, że badając strukturę niewerbalną i nieimażynistyczną nie można arbitralnie dowieść, że zawiera ona określoną treść ani, tym bardziej, jej scharakteryzować. Fenomenologia muzyki stwierdza istnienie zawartości treściowej muzyki instrumentalnej, w tym treści ideologicznej, lecz odczytuje tylko łatwe do odczytania i trudne do zakwestionowania fragmenty tej treści - tytuły utworów muzycznych. Jednak i ten dowód na to, że muzyka komunikuje coś więcej niż własny przebieg kompozycyjny jest ważną wskazówką. Współcześnie, nawet tzw. muzyce czystej towarzyszy zwykle cień rzeczywistości pozamuzycznej w postaci tytułu utworu. Opatrzenie utworu muzycznego tekstem ukierunkowuje go pojęciowo i w ten, choćby jak najbardziej zewnętrzny sposób, włącza muzykę w nurt spraw na ogół dalekich od czystej estetyki.

20 Por.: S. Kisielewski, Czy tryumf ,, Realizmu”, w: Muzyka i mózg, S. Kisielewski, Kraków 1974, s. 56. 
Rzecznicy autonomii estetyki dzieła muzycznego i zwolennicy normatywizmu estetycznego inaczej pojmują cel istnienia twórczości muzycznej, w tym cel najbardziej pierwotny, który doprowadził do jej powstania. Według „,autonomistów” muzyka powstała jako medium wolnej ekspresji, akt samorealizacji pozbawiony intencji ukierunkowanego oddziaływania na słuchacza. Jedyne społeczne cele jej istnienia upatrują w dostarczaniu przyjemności estetycznej i pewnym szczególnym rodzaju edukacji - odbiór kompozycji muzycznej wymaga sprawności intelektualnej ${ }^{21}$ i określonego typu wrażliwości. Muzyka utożsamiana jest tu ze sferą wolności, która nawet w systemach autorytarnych wydaje im się trudna do naruszenia. Polityczna funkcja muzyki, którą dostrzegają ,,autonomiści” sprowadza się do ochrony swobód obywatelskich w ramach wąskiej sfery, jaką jest kontakt ze sztuką muzyczną. Z pobłażliwością odnoszą się oni do badań socjologicznych i kulturologicznych, które ujawniają społeczny i polityczny rodowód muzyki. W centrum zainteresowania stawiają zwykle złożone formy muzyczne, pomijając formy najprostsze, w tym grupy rytmiczne będące najbardziej pierwotnym źródłem muzyki. W tak ograniczonym polu badań polityczna natura muzyki nie może być w pełni rozpoznana.

Z analiz socjologiczno-muzykologicznych ${ }^{22}$ wynika, że muzyka - która kształtowała się na bazie sztuki rytmicznej ${ }^{23}$ - zrodziła się z potrzeby zintensyfikowania zbiorowych działań. Prototypem śpiewu są rytmicznie artykułowane dźwięki ulgi wydawane podczas pracy. Początkowo to one towarzyszyły rytmicznie powtarzanym czynnościom (zrytmizowanie czynności zmniejsza wydatek energii). Organizacja wspólnej pracy jest

21 Nie jest zresztą pewne czy słuchanie utworu muzycznego ze zrozumieniem wymaga zaangażowania intelektu. Amerykańscy psycholodzy twierdzą, że percepcja muzyki nie jest czynnością stricte intelektualną. Ich badania dowodzą, że iloraz inteligencji studentów Akademii Muzycznych jest znacznie niższy niż studentów innych uczelni. Zob.: R. Jourdain, Music, the Brain and Ecstasy. How Music Captures Our Imagination, New York 1997, s. 162.

${ }_{22}$ Zob.: np. K. Büchner, Arbeit und Rhytmus, Leipzig 1924; K. Kelles-Krauz, Kilka głównych zasad rozwoju sztuki, w: Pisma wybrane, K. Kelles-Krauz, Warszawa 1952; S. Ossowski, Socjologia sztuki (przeglad zagadnień), „Przegląd Socjologiczny” 1936, t. 4, z. 3-4; L. Krzywicki, Dzieje wysiłku fizycznego, „Prawda” 1898, nr 3-7; J. Reiss, Socjologiczne podłoże ślaskiej pieśni ludowej, w: O społecznych problemach muzyki ..., M. Demska-Trębaczowa, s. 185.

23 Spośród trzech składników budulcowych muzyki: melodii, harmonii i rytmu, rytm jest składnikiem najbardziej pierwotnym. Zob.: R. Jourdain, Music, the Brain and Ecstasy ..., s. 28. 
najłatwiejsza, gdy towarzyszy jej cykliczny dźwięk - uderzenia młota, siekiery lub innego narzędzia. Jeśli praca ma charakter cichy, rytmiczny śpiew staje się skutecznym środkiem dyscyplinującym, w sposób bezwiedny angażujący człowieka w jednostajne tempo działania. Rytm wprowadza element karności i ładu, budzi wśród pracujących poczucie spójni dlatego też muzyka propagowana w reżimach totalitarnych miała nieskomplikowaną linię melodyczną i silnie zaznaczony rytm. Popularna była rytmika marszowa, oparto na niej większość pieśni wykonywanych między innymi przez słowiańskie chóry narodowe. Nostalgiczność i rzewność pieśni ludowej ożywiano nagła, nieoczekiwaną zmianą rytmu. Charakterystyczne są tu szybkie przejścia z jednego zespołu 2-4 głosów unisono w inny, a także nagłe ,podchwytywanie” melodii przez głos wiodący, „który wyrasta niby kwiat spod ziemi”"24. Rytmiczna muzyka płynęła z głośników w halach fabrycznych by uprzyjemnić pracę kolektywu zakładowego i stymulować go do ciagłego i pozornie nienużącego wysiłku $^{25}$. We współczesnych państwach liberalno-demokratycznych muzyka towarzyszy nie tylko procesowi wytwarzania towaru, lecz, przede wszystkim, procesowi jego sprzedawania - jest bodźcem stymulującym zakupy. Potencjalny klient osiaga - gratis - pewien poziom przyjemności, wchodząc do pomieszczenia sklepowego wypełnionego muzyką. Jego zdolność do krytycznej oceny oferowanego towaru zostaje zaniżona ${ }^{26}$. W naturalny sposób dąży do zintensyfikowania przyjemności poprzez nabycie oferowanych produktów. Jeśli coś stanie na przeszkodzie zakupom, zapamięta moment niezrealizowanej satysfakcji i - z dużym prawdopodobieństwem - powróci do sklepu innego dnia. Muzyka wykorzystywana jest w reklamie telewizyjnej, stanowiąc uzupełnienie dla wyidealizowanych obrazów komfortu życia, gwarantowanego pod warunkiem zakupu reklamowanych towarów ${ }^{27}$. Ta sama muzyka odtwarzana w pomieszczeniach sklepowych przywołuje w wyobraźni konsumenta znane obrazy

24 W. Asafjew, Kompozitor - Imia jemu narod, „Sowietskaja Muzyka” 1949, nr 2, s. 62 .

25 Zob.: A. Matejko, Kultura pracy zbiorowej, Warszawa 1962, s. 45.

26 Już w czasach Romantyzmu zauważono, że przy jednoczesnym zaangażowaniu wzroku i słuchu upośledzona zostaje zdolność do refleksji. Por.: T. Adorno, Prolog do telewizji, w: Sztuka i sztuki. Wybór esejów, T. Adorno, Warszawa 1990. s. 59.

27 O reklamie zob. np.: R. Paradowski, Religia, ideologia totalitarna, reklama I, II, „Społeczeństwo Otwarte” 1996, nr 2, 3; R. Paradowski, P. Załęcki, Kulturowe instrumentarium panowania, Toruń 2002. 
i zakodowany z ich pomocą podświadomy nakaz kupowania. W ten sposób funkcjonuje jako skuteczny instrument urabiania homo-schopping.

Im bardziej cofniemy się w historię ludzkości, tym lepiej widać, że muzyki i jej pochodnej - tańca - nie uprawiano jako rozrywki czy manifestacji czysto artystycznej, lecz że wiązała się ona z organizacją życia społecznego. Muzyka i taniec od początku swego istnienia wiązały się z najważniejszymi czynnościami i zdarzeniami życiowymi, dowodem na to są tańce religijne, tańce wojenne ${ }^{28}$, tańce weselne, tańce śmierci ${ }^{29}$, tańce ściśle związane z pracą, a nawet tańce związane z procedurą sądowniczą ${ }^{30}$. Kultura muzyczna powstaje w ramach określonej struktury społecznej i politycznej, wyraża charakter i temperament narodu tworzącego tę strukturę. Najbardziej jest on czytelny w muzyce zawierającej cytaty z folkloru czy melodii patriotycznych, lecz nawet w muzyce pozbawionej tego rodzaju odniesień indywidualny rys narodowy jest wyczuwalny i zrozumiały dla innych narodów, choć niemożliwy do zdefiniowania. Każdy naród ma własny typ wyobraźni słuchowej ${ }^{31}$, związany ze znajomością muzyki folklorystycznej i dzieł kompozytorów narodowych. Charakter narodowy muzyki utrwala się dzięki temu, że kompozytorzy pisząc utwory stosują środki łatwo trafiające do swoiście uformowanej wyobraźni słuchowej swych najbliższych odbiorców nawet wtedy, gdy ich własna wyobraźnia jest nieograniczona. Muzyka narodów Europy Zachodniej oparta jest na systemie dur - mol, czyli gam ośmiostopniowych, gdzie każde kolejne dwa stopnie rozdzielone są bądź półtonem, bądź całym tonem. Rozmieszczenie tych tonów definiuje gamę i harmonię.

28 Taniec wojenny nie tylko integruje wojowników - dopóki trwa przyciaga wszystkich, którzy znajdują się w zasięgu słyszalności - lecz ma za zadanie odstraszać wrogów. Jego istotą jest szybkie, rytmiczne powtarzanie kroków. Ich odgłos słyszany z oddali sprawia wrażenie, że wojowników jest więcej niż w rzeczywistości. Intensywność kroków zastępuje tu dużą liczbę tańczących. Zob.: E. Canetti, Masa i władza, Warszawa 1996, s. 35.

29 W Afryce Środkowej w pogrzebie uczestniczą w miarę możliwości wszyscy mieszkańcy wsi. Rozpacza tylko bliska rodzina zmarłego, dla innych pogrzeb jest okazją do spotkania i wspólnego spędzenia czasu, czemu na ogół towarzyszy śpiew i tańce, tzw. „tańce śmierci”.

30 W kulturze ludowej Kongo przeprowadza się procesy sądowe z pomocą muzyki i tańca. Powód i pozwany wspomagani są przez grupy swych obrońców śpiewanymi interwencjami. Wyrok ogłasza się biciem w tam-tamy, po nim następują rytualne tańce.

31 Zob.: Z. Lissa, O stylu narodowym, w: O społecznych problemach muzyki ..., M. Demska-Trębaczowa, s. 133. 
W muzyce hinduskiej, pakistańskiej i irańskiej zamiast półtonów istnieć mogą ćwierćtony lub 3/4 tony, przez co uzyskuje się efekt odbierany przez Europejczyków jako fałsz, podczas gdy dla narodów azjatyckich jest pełnym wyrazu zwrotem muzycznym. Muzyka jest utrwalanym elementem świadomości narodowej i niejako emblematem narodów. Znamiennym jest fakt, że w momentach spadku znaczenia lub zagrożenia jakiejś grupy społecznej lub etnicznej, grupa ta dąży nie tylko do zachowania, lecz do podkreślenia swej odrębności form życia i sztuki, w tym muzyki. Jest to forma rekompensacji grupowej, z niej wywodzą się, między innymi, XIX i XX-wieczne tendencje do egzotyki. W starożytnej Grecji upadek znaczenia miast greckich wywołał nasilenie indywidualizmu w muzyce - odwrót od surowej diatoniki i narodziny enharmoniki ${ }^{32}$. Muzyka Murzynów amerykańskich przetrwała wskutek segregacji rasowej i dyskryminacji, wiele $\mathrm{z}$ ich pieśni - $\mathrm{w}$ tym pieśni religijnych - mając charakter protestu urosło do rangi symbolu narodowego.

Skupiając w sobie indywidualne cechy, wartości, emocje, ideały grup społecznych i całych narodów, muzyka niejako reprezentuje je i afiszuje. Funkcja reprezentacyjna jest odmianą funkcji integracyjnej, niwelującej różnice wewnątrz grupy. Ostatecznie wykształciła się na przełomie Średniowiecza i Renesansu wraz ze wzrostem przepychu życia dworskiego. Muzyka stała się emblematem monarchii i władzy królewskiej, była główną częścią ceremoniału służącego ich wychwalaniu. Dwory rywalizowały ze sobą w tworzeniu oprawy muzycznej życia dworskiego, była to sprawa prestiżu politycznego. Wiedeń stał się europejskim centrum muzycznym dzięki Habsburgom, którzy chcieli dorównać dworowi francuskiemu, z jego Musique de roi, Divertissements i Comédies-Ballets. Ludwik XIV, chcąc zaćmić konkurencję swym nowatorstwem, wprowadził kapelę królewską do kościołów. Dzięki temu, różne warianty Te Deum wykonywane w paryskich kościołach z okazji istotnych wydarzeń politycznych $^{33}$ zabrzmiały w wersji instrumentalnej, co było zjawiskiem unikalnym. Niezwykłe było także wprowadzenie stylu operowego do muzyki sakralnej. W życiu muzycznym Europy powstawały stronnictwa muzyczne, które nieraz przekształcały się w stronnictwa polityczne. Bywało też odwrotnie - stanowiska, jakie zajmowano wobec muzyki i kompozyto-

32 Zob. Z. Lissa, Aspekt socjologiczny w polskiej muzyce współczesnej, w: O społecznych problemach muzyki ..., M. Demska-Trębaczowa, s. 116.

33 Kapela królewska grała w kościołach, między innymi, z okazji uczczenia ratyfikacji pokoju z Niemcami w 1679 r. i z okazji urodzin księcia Burgundii w 1682 r. 
rów, dyktowane były motywami politycznymi. Znane są też w historii podziały na różne klany, których program ideowy składał się z elementów estetycznych i postaw politycznych, wspomnieć tu warto gluckistów i piccinistów, spierających się o wyższość muzyki francuskiej nad włoską w XVIII w. czy też ugrupowania dyskutujące o znaczeniu oper Verdiego i szkół narodowych w XIX wieku. Te dyskusje i konflikty angażowały nie tylko melomanów, lecz także osoby niezainteresowane muzyką ${ }^{34}$.

Jedna ze szczególnych, najwcześniej rozwiniętych funkcji muzyki sprowadza się do gloryfikacji władzy politycznej i osobistości, które ją reprezentują. Z czasów starożytnych zachowały się spisane przez Swetoniusza kuplety, śpiewane prze Rzymian na cześć Cezarów. Bardzo charakterystycznym przykładem pompatycznej quasireligijnej muzyki na cześć króla są oratoria Haendla oraz jego Muzyka na wodzie i Muzyka sztucznych ogni. Początki opery także wiążą się z afirmacją władzy królewskiej. Wszystkie teatralno-muzyczne dzieła sceniczne, pochodzące z okresu poprzedzającego pojawienie się teatrów publicznych były dziełami okazjonalnymi, związanymi z interesami politycznymi dworów, dla których były pisane ${ }^{35}$. Najwcześniejsze opery zamawiano do wykonania podczas uroczystości zaślubin królewskich i koronacji, łączących tożsamość rodziny panującej z tożsamością państwa. Stawały się one czytelne w określonych kontekstach, w których zarówno dla rodziny panującej, jak i zaproszonych gości, to co osobiste miało jednocześnie wymiar polityczny. Opery, tak jak wydarzenia którym towarzyszyły, mogą być odczytywane jako dokumenty polityczne, w których - jak w życiu dworskim - kwestie osobiste mieszają się z polityką̨ ${ }^{36}$. Fakt, iż muzyka od starożytności po współczesność wiązała się z procedurą zamówienia jest świadectwem paraliżu jej autonomiczności. Muzycy w czasach starożytnych zobowiązani byli do pisania muzyki podtrzymującej kult bogów i cezarów ${ }^{37}$ (dopiero po dru-

34 Zob.: I. Supičič, Wstęp do socjologii muzyki ..., s. 104.

35 Zob. np.: L. Bianconi, T. Walker, Production, Consumption and Political Function of Seventeenth Century Italian Opera, „Early Music History” 1984, s. 209-296; cyt. za.: S. G. Cusick, O kobietach, muzyce $i$ władzy: model z siedemnastowiecznej Florencji, „Muzyka” 2001, nr 2 (181), s. 101.

36 Por. np. schemat oper Periego, Rinucciego (Eurydyka), Monteverdiego, Striggia (Orfeusz), Monteverdiego, Rinucciego (Arianna). Bohaterami tych oper są sprawiedliwi i miłosierni niebiańscy władcy świata i ich ziemskie kopie - królowie, mecenasowie tych dzieł.

37 Życie artystyczne i sportowe Sparty sprowadzało się do zbiorowych manifestacji patronowanych przez państwo, mających charakter powszechnych świąt religijnych. 
giej wojnie meseńskiej [645-628] rozwinęła się w Sparcie muzyka chóralna wykonywana przez kobiety, nie obciążona obowiązkiem przesłania patriotycznego). Średniowieczni muzycy pisali utwory wyłącznie na potrzeby kościoła aż do czasu, gdy walka z daninami na rzecz papieży i rozwój kultury mieszczańskiej spowodowały rozdzielenie funkcji obsługi władzy kościelnej i świeckiej. Dopóki królowie i książęta stanowili rdzeń społeczeństw, olbrzymia część muzyki powstawała - przynajmniej teoretycznie - wyłącznie dla nich. Ich otoczenie korzystało z niej jedynie dodatkowo i niemal bezprawnie ${ }^{38}$. Współcześnie dokonująca się komercjalizacja sztuki oparta na manipulacjach konsumpcyjnych ma na celu maksymalne upowszechnienie i wykorzystanie wszystkiego co zgodne z gustem masowego odbiorcy. Konieczność uwzględniania tego gustu degraduje artystę do rangi drobnego sprzedawcy ${ }^{39}$. Muzyka opatrzona etykietą niekomercyjności i ekskluzywności najczęściej jest subwencjonowana przez swoich mecenasów - Ministerstwo Kultury i Sztuki, Uniwersytety, dobrze prosperujące firmy handlowe, fundacje. Muzycy mają wobec nich określone zobowiązania. I w tym przypadku artysta staje się urzędnikiem, któremu ogranicza się swobodę inicjatywy. Porozumienie między mecenasem i artystą nie zawsze było idealne, jednak dziś są sobie znacznie bardziej obcy niż w epoce absolutyzmu ${ }^{40}$ - najczęściej mecenas nie ma żadnego stosunku do utworu muzycznego swego protegowanego, a tzw. sponsoring jest częścią prowadzonej przez niego strategii podatkowej i reklamowej.

Od Renesansu aż po wiek XIX wśród instrumentalistów najbardziej prestiżową pozycję zajmowali trębacze i dobosze. Oni najwcześniej zdobyli trwałe miejsce na dworach feudałów, gdzie wykonywali uroczyste fanfary podczas świąt, turniejów rycerskich, wypraw wojennych itp. Związana z reprezentacją i wyprawami wojennymi trąba była instrumentem zastrzeżonym jedynie do użytku feudałów, istniał zakaz zatrudniania trębaczy i doboszów w miastach. Organizacja życia miejskiego odbywała się z pomocą dźwięku rogu wydawanego przez strażników miejskich,

38 Dla wszystkich pisana była muzyka okolicznościowa, związana ze świętami kościelnymi i państwowymi. Wyłonienie się publiczności uprzywilejowanej zapoczątkowało rozwój kameralistyki. Zob.: I. Supičič, Muzyka i publiczność, w: Wstęp do socjologii muzyki ..., I. Supičič, s. 54.

39 Por.: B. Schäffer, Socjologia muzyki współczesnej, w: O społecznych problemach muzyki ..., M. Demska-Trębaczowa, s. 197.

40 Zob. T. Adorno, Filozofia nowej muzyki ..., s. 53. 
zajmujących ważne miejsce w hierarchii administracyjnej. Dźwięk rogu ostrzegał przed pożarem i innym niebezpieczeństwem zagrażającym miastu, a także odmierzał upływ czasu ${ }^{41}$. Ostatecznie jednak to fanfary i werble, nierzadko ozdobione haftowanymi herbami, stały się symbolem władzy monarszej ${ }^{42}$ lub - jak w czasach Rewolucji Francuskiej - władzy ludu i zwycięstwa. W rewolucyjnej Francji powstał prototyp muzyki charakterystycznej potem dla reżimów totalitarnych. Od kompozytorów zażądano tworzenia utworów chóralnych, które mogłyby wykonywać thumy oraz utworów instrumentalnych dla dużych orkiestr dętych i zespołów bębnów, które mogły koncertować na wolnym powietrzu. Sytuacja polityczna warunkowała kształtowanie tzw. rewolucyjnego gustu muzycznego, pełnego głośnych i brutalnych efektów obrazujących determinację mas i siłę wojskową - a przez to budzącą nastroje wojownicze, gustu preferującego regularność, zrozumiałość i prostotę linii melodycznej. W muzyce rewolucyjnej, wykorzystywanej potem i przetwarzanej dla potrzeb totalitaryzmów jej funkcja polityczna osiagga kulminację i staje się priorytetowa.

W reżimach totalitarnych otwarcie i obowiązkowo łączyło się twórczość muzyczną ze służbą ideologiczną ${ }^{43}$. Premiowano w niej melodyjność i maksymalne uproszczenie środków technicznych. Zamierzona łatwość wykonawcza nieraz sprowadzała muzykę do kiczu ${ }^{44}$. Estetycy socrealizmu postulowali programowość muzyki (miała uświetniać epos o wysiłku narodów w tworzeniu nowej, lepszej przyszłości, a także wzruszać), dokonując jednocześnie podziału na gatunki muzyczne mniej lub bardziej sprzyjające komunistycznej lub faszystowskiej propagandzie. Premiowano wokalność, związanie muzyki z optymistycznym i patetycznym tekstem, rozwinęła się zatem niebywale produkcja sztampowych pieśni masowych ${ }^{45}$.

41 Zob.: Z. Chaniecki, Powstanie zawodu i działalność organizacyjna muzyków w Europie, w: O społecznych problemach ..., M. Demska-Trębaczowa, s. 53.

42 Symbol ten funkcjonuje także na gruncie religijnym, o czym świadczy chociażby codzienny tusz towarzyszący kultowi ikony Matki Boskiej Częstochowskiej.

43 Zob. np.: N. S. Chruszczow, Wysoka ideowość i mistrzostwo artystyczne wielka siła radzieckiej literatury $i$ sztuki. Przemówienie na spotkaniu przywódców partii i rzqdu z działaczami literatury i sztuki 8 marca 1963, „Kraj Rad”, wydanie specjalne, Warszawa 1963.

44 Zob.: T. Brodniewicz, Za i przeciw hitleryzmowi-muzyka w Trzeciej Rzeszy, w: Muzyka i totalitaryzm, pod red. M. Jabłońskiego, J. Tatarskiej, Poznań 1996, s. 23.

45 W ZSRR najbardziej popularne były pieśni Izaaka Dunajewskiego do słów Demiana Biednego, w Niemczech - pieśni Georga Blumenstaata, Herberta Naperskyego, Waltera Reina, Adolfa Seuferta i Heinricha Spitta. 
Trochę tylko mniej popularne były marsze i symfonie ${ }^{46}$, a także - głównie w Niemczech - opera narodowa. Tu najważniejsza stała się ekspresja, nawet kosztem rezygnacji z klasycznego przetworzenia tematu, co widać w formach wagnerowskich. W dawnej operze aż do Karola Marii Webera funkcję gestu przerywnikowego w operze pełniły partie orkiestrowe podczas recytatywów. Należały one do kompozycji opery i nie były nadmiernie eksponowane. Wagner gesty te powtarza i wzmacnia, lecz nie rozwija ich, przez co czyni ekspresję z jednej strony czytelną nawet dla mało wyrobionego słuchacza z drugiej - wikła się w patetyczne dłużyzny widoczne nawet $\mathrm{w}$ najmniejszych komórkach formy ${ }^{47}$. W kompozycji oper i symfonii doszło zresztą także do uproszczeń - zrezygnowano z wieloobsadowych poematów symfonicznych na rzecz kompozycji mniejszego formatu. Opery „kurczyły się” do jednoaktówek, miejsce wybujałych rozwiązań harmonicznych zajął linearyzm. Styl Neue Sachlichkeit często o groteskowym zabarwieniu wyparł wcześniejszy „romantyczny porządek estetyczny" ${ }^{\prime 4}$. Odrzucono muzykę atonalną, szczególnie nierodzimego pochodzenia, niezrozumiałą dla masowego odbiorcy. Niechęć do dysonansów wynikała nota bene nie tylko z postulatu przystępności dla mas: dysonanse odzwierciedlają stan niespójności, chaosu, nieadekwatności i jako takie mogły być nieznośne dla głosicieli utopii, którzy unikali doświadczenia, a tym bardziej rozprzestrzeniania wątpliwości co do spójni idei i rzeczywistości politycznej. $Z$ drugiej strony, muzyka atonalna wyraża protest przeciwko wykorzystaniu muzyki o tradycyjnych środkach wyrazu w jakichkolwiek celach pozaestetycznych. Celem kompozytorów muzyki atonalnej było stworzenie dzieł, które niełatwo spożytkować dla podkreślenia rzeczywistości pozamuzycznej, szczególnie - o czym byli przekonani - fałszywej, zakłamanej. Dla przywódców państw totalitarnych intencja ta była czytelna. Tonalność w zakresie muzycznych środków warsztatowych odpowiadała postulatowi realistycznej figuratywności w sztukach plastycznych. Odwrót od figuralności rozumiany był jako wykręt od obowiązku odzwierciedlania i powielania kreowanej rzeczywistości poli-

46 Ulubionymi utworami Lenina była szósta symfonia Czajkowskiego i Appasionata Bethovena. Twierdził, że trafnie wyrażają walkę społeczną. Por.: A. Alszwang, W. Cukkerman, Ljubimyje muzykal nyje proizwiedienija Lienina, „Sowietskaja muzyka" 1949, nr 1.

47 Zob. T. Adorno, Filozofia nowej muzyki ..., s. 17.

48 M. Jabłoński, Muzyka zdegenerowana. Uwagi do historii pewnej wystawy, w: Muzyka i totalitaryzm, pod red. M. Jabłońskiego, J. Tatarskiej, Poznań 1996, s. 39. 
tycznej. Przyczynę powstania abstrakcjonizmu w malarstwie wskazano zresztą prawidłowo - wykształcił się on z niechęci do kopiowania rzeczywistości, z obawy by malowane obrazy nie stały się zmechanizowanym towarem użytkowym, jakim w początkach swego istnienia była fotografia. Muzyka tonalna wspomagała sakralizację i teatralizację nazizmu i stalinizmu, służyła podtrzymywaniu kultów, funkcja polityczna, jaką spełniała, daje się sprowadzić do funkcji quasi-religijnej.

W państwach totalitarnych jawnie mówiło się o służebnej roli sztuki, jej funkcja estetyczna była postrzegana jako drugorzędna. Rozwój form muzycznych był sterowany. Promowano i eliminowano gatunki muzyczne według kryterium przydatności/szkodliwości dla reżimu. We współczesnych państwach demokratycznych nie ogranicza się rozwoju form muzycznych i nie eksponuje się utylitarnych funkcji muzyki, sugerując raczej, iż jest ona kulturowym medium wolności, a twórca jest nieskrępowany żadną ideologią. W rzeczywistości sztuka muzyczna nadal pełni rolę narzędzia integracji i podporządkowania ideologiom, już to ideologii jedności ludu bożego i posłuszeństwa Bogu i kościołom, już to ideologii powszechnego i nieuniknionego wciągnięcia w ramy kultury konsumpcyjnej i podporządkowania się wyznaczanym przez nią regułom. W państwach liberalno-demokratycznych, gdzie wolność realizowana jest z powodzeniem tylko w sferze ekonomii ${ }^{49}$, muzyka jest nawet bardziej uwikłana w służbę ideologii niż w czasach rozwoju totalitaryzmów. Istniał bowiem wtedy margines dla sztuki uznanej za nieprzydatną dla realizacji programów totalitarnych - muzyka atonalna, nierodzima (jazz, afro, latino), szczególnie wyrafinowana pod względem warsztatowym. Ten rodzaj muzyki istniał w funkcji opozycji do muzyki oficjalnej i integrował twórców oraz publiczność opozycyjną w stosunku do ideologii totalitarnej. Funkcjonował ponadto podział na obszary sztuki niskiej i wysokiej, próby szerokiego udostępnienia obu tych obszarów nie zatarły ich granic. Dziś margines dla muzyki, której przemysł kulturowy nie wykorzystuje jest bardzo wąski i stale się zmniejsza. Komercjalizacja dokonująca się zarówno w sferze prywatnej, jak i publicznej, wiąże się z umasowieniem wszystkich elementów kultury. W kampaniach reklamowych wykorzystuje się wszystkie istniejące rodzaje i gatunki sztuki, nie wyłączając współczesnej muzyki eksperymentalnej. Przemysł kulturowy sumuje wszystkie - histo-

49 Zob. np.: R. Paradowski, Demokracja i panowanie, w: Kulturowe imperium panowania, pod red. R. Paradowskiego, P. Załęckiego. 
ryczne i współczesne - elementy kultury w nową jakość, przy czym łączą się, rozdzielane przez tysiąclecia, obszary sztuki wysokiej i niskiej. Utwory muzyki klasycznej, które niegdyś sytuowały się na obszarze sztuki wysokiej, są niezmiernie użyteczne z punktu widzenia zasad marketingu podkreślają ekskluzywność oferowanych produktów, niektóre z nich stały się przez to bardzo powszechne, tracąc swą elitarność. Kultura konsumpcyjna czyni masowym to, co nie było tworzone jako masowe, w tym utwory o najwyższym poziomie artystycznym i intelektualnym. Zaczynają one funkcjonować niejako na dwóch różnych szczeblach kultury - Kultury jako takiej, która stanowi ów niewielki margines i kultury konsumpcyjnej, która absorbuje i przetwarza wszystko, co może służyć wychowaniu konsumenta: wzbudzeniu w nim przekonania o konieczności nabycia oferowanej masy towarowej oraz zmotywowaniu do pracy, która jest głównym sposobem zdobycia pieniędzy. Wychowanie konsumenta, gdzie muzyka jest chętnie stosowanym, bo sugestywnym acz łagodnie działającym środkiem, jest quasitotalitarnym programem dyscyplinowania i sterowania społeczeństwami konsumenckimi. Jego istota i cele są kamuflowane - akcentuje się kwestię wychowania, ujmowaną najczęściej w kategoriach ogólnie pojętego kształcenia, a pomija się przedstawienie zamierzonych rezultatów tego wychowania, których uosobieniem jest homo schopping. Pozwala to uniknąć niewygodnej w warunkach liberalnej demokracji debaty na temat stanu wolności w sferze publicznej. Masowe upowszechnianie dzieł sztuki muzycznej milcząco zakłada kształcenie estetyczne obywatela. Rozwój percepcji estetycznej jest jednym ze sposobów rozszerzania świadomości, tymczasem wychowanie konsumenta sprowadza się do jej zawężenia w stopniu umożliwiającym manipulację. Zatem faktyczne kształcenie estetyczne w kulturze konsumpcyjnej odbywać się nie może, gdyż nie jest zgodne z jej interesami. Kultura konsumpcyjna sama ujawnia zresztą, iż nie chodzi o prawdziwe kształcenie, nie robiąc różnicy między autentycznym dziełem sztuki (a tylko ono może być podstawą kształcenia estetycznego), a dalekim jego echem, które w postaci masowego produktu dociera do konsumenta. Muzyka klasyczna skojarzona z obrazem reklamowanego produktu lub jej uproszczony, zubożony pod względem środków artystycznych fragment lub wariacja, motyw klasyczny zespolony z tekstem reklamy i przerobiony w ten sposób w popularną piosenkę, sygnał telefonu komórkowego lub dzwonka do drzwi - wszystko to jest materiałem manipulacyjnym, wykorzystywanym w kolejnych etapach procesu produkcji i zbytu. Co prawda przekształcenie twórczości muzycznej w artykuł masowo stosowany i na masy oddziałujący trwało 
dłużej niż analogiczny proces w literaturze czy sztukach plastycznych. Bezpojęciowość materii muzycznej zdawała się utrudniać spożytkowanie jej jako środka stymulacji popytu i podaży. Szybko jednak zorientowano się, że właśnie irracjonalność i abstrakcjonizm cechujące muzykę, pozwalają na jej uniwersalne wykorzystanie. Umasowienie twórczości muzycznej odbywa się zawsze zgodnie z wymogiem przystępności wykonania, rozrywkowości i zmysłowej efektywności - odgórnie zintegrowana, przyzwyczajona do nieuważnego słuchania publiczność konsumencka wyławia z niej tylko elementy najprostsze: zapamiętane wcześniej motywy rytmiczne i sentymentalne oraz wywołane przez nie nastroje. Konsument nie zastanawia się nad uczuciem pod wpływem którego muzyka powstała, ważne dla niego jest tylko uczucie, które muzyka w nim budzi, a budzić powinna - zgodnie z założeniem producentów reklam i przedsiębiorców handlowych a jednocześnie zgodnie z oczekiwaniem samych konsumentów (wychowanie konsumenta gwarantuje tu równoległość oczekiwań) uczucie przyjemności. Dawniej muzyka pełniła funkcję dekoracji dworów królewskich i świątyń, dziś dekoruje dosłownie wszystko. Nie pozbyła się zatem funkcji estetycznej, choć wywoływanie wrażeń estetycznych nie jest dziś jedynym czy choćby głównym zadaniem muzyki. Przyjemność jest zaledwie punktem wyjściowym w złożonym procesie oddziaływania na świadomość społeczną.

Komercjalizacja obejmuje wszystkie składniki kultury, w tym religię. Religia z zasady dąży do uzyskania niepodważalnego statusu składnika wyjątkowego, nieodzownego dla jej istnienia (model kultury całkowicie świeckiej nie jest w niej brany pod uwagę jako niezgodny z religijnym rozumieniem kultury en bloc). Świadectwem statusu religii w kulturze jest liczba wyznawców. Stara się więc ona, poprzez swoje media, przyciagnąć i zatrzymać w strefie swego wpływu jak najwięcej osób. Religia chrześcijańska nie jest tu oczywiście wyjątkiem, a nawet wśród innych religii wyróżnia się dużą sprawnością oddziaływania, dzięki użyciu różnorodnych instrumentów, których skuteczność medialna sprawdzona została już w innych rejonach kultury. Środki masowego przekazu, wydawnictwa, plakaty i dewocjonalia są nośnikami reklamy religijnej i jednocześnie towarem, który jest oferowany według wszelkich praw komercji. Ale przecież najważniejsze, co Kościół ma do zaoferowania to ideologia chrześcijańska. Wdzięcznym, skutecznym i w dodatku tradycyjnym sposobem oferty jest pieśń religijna śpiewana unisono, która wraz z postanowieniami Soboru Watykańskiego II zabrzmiała w językach narodowych, wypierając chorał gregoriański i polifonię. Dopóki śpiew odbywał się wyłącznie z akompa- 
niamentem organów nie było wystarczających podstaw do twierdzenia, że muzyka religijna także została wciagnnięta do skomercjalizowanej produkcji masowej. Dziś nie ma co do tego wattpliwości. Zgodnie z postulatem inkulturacji sformułowanym przez najwyższe gremia kościelne ${ }^{50}$ Kościół uwzględnia specyfikę kulturową, starając się dostosować formę kultu do jej charakteru. Skoro w Europie dominującą rolę odgrywa kultura komercyjna - skomercjalizowano muzykę religijną. Otworzyło to możliwości oddziaływania na wszystkie grupy społeczne, powstała religijna twórczość muzyczna przeznaczona dla dzieci i przez nie wykonywana ${ }^{51}$, religijna muzyka młodzieżowa prezentowana szeroko najczęściej przez uczestników katolickiego ruchu młodzieżowego „Oaza”, piosenki pisane dla wiernych w średnim i starszym wieku, nierzadko wykorzystujące melodie popularnych przebojów i lansowane jako przeboje. Najwięcej starań Kościół poświęca pozyskaniu dzieci i młodzieży. Starania te owocują zróżnicowaniem stylistycznym twórczości adresowanej zwłaszcza do tej ostatniej grupy społecznej - w wykonaniu „oazowym” można usłyszeć zarówno piosenki o proweniencji harcerskiej, jak i rock wykonywany na perkusji i gitarach elektrycznych. Niezgodnie z dyrektywą inkulturacji, lecz ku zadowoleniu społeczności religijnej, młodzież chętnie naśladuje muzykę negro spirituals, choć nie jest to, niestety, naśladownictwo udane - improwizacja na materiale skali blusowej nie jest swobodna, a intonowanie blue notes jest niewłaściwe ${ }^{52}$, nie mówiąc o tym, że rodzima tradycja liturgiczna powstrzymuje wykonawców od śmiałego zaatakowania dźwięku, a tym bardziej poruszania się w rytm muzyki. Jest to mimo wszystko chętnie oglądane widowisko, podnoszone do rangi imprezy kulturalnej. Koncerty tego rodzaju przyciagają większe tłumy niż organizowane także w kościołach koncerty klasycznej muzyki religijnej.

Zasada przystępności i nie zmuszania do wysiłku percepcyjnego spowodowała również skrócenie czasu trwania nabożeństw. Partie wokalne tekstu liturgii zostały możliwie zredukowane, mimo to, msze śpiewa się

50 Art. 119 Kodeksu liturgicznego zatwierdzonego przez Sobór Watykański II mówi o konieczności uwzględniania lokalnej tradycji muzycznej w miejscach kultu, gdyż ma to znaczenie dla kształtowania zmysłu religijnego. Zob.: M. Pieczykolan, Ancilla theologiae, ancilla populi. O fundamentalnej roli, jakq Kościół może i powinien odgrywać w wychowaniu muzycznym narodu, cz. I-IV, „Ruch Muzyczny” 2000, nr 10-14.

51 Przykładów tego rodzaju twórczości może dostarczyć repertuar zespołu „Arka Noego".

52 Por.: M. Pieczykolan, Ancilla theologiae, ancilla populi ..., nr 14, 2000. 
na ogół tylko w dni świąteczne, na codzień wokalizę zastępuje się rytmiczną recytacją, a śpiew pieśni religijnych ogranicza się zwykle do jednej lub dwóch zwrotek. Akompaniament, jeśli w ogóle występuje, sprowadza się do kilku ubogich akordów w skali dur - moll.

Muzykolodzy ubolewają nad kondycją muzyki we współczesnym świecie, gdzie zacierają się wszelkie kryteria jej wartościowości i bezwartościowości znane i uznawane co najmniej do połowy XX wieku. W kulturze komercyjnej miarą wartości jest użytkowość, a każdy rodzaj muzyki może być spożytkowany przez pomysłowych przedsiębiorców i specjalistów do spraw reklamy. Funkcjonalność sztuki muzycznej, a raczej jej mocno zużytej warstwy zewnętrznej stale wzrasta, podczas gdy jej warstwa wewnętrzna pozostaje odrzucona, wymieniona na inną lub nigdy nie jest wydobywana na zewnątrz.

\section{Summary}

This paper contains - in the historical context - the analysis of musical forms as an efficacious and sufficiently universal means of acting, governing, assembling and putting under discipline different societies (including nations) that are considered as a unity, as well as respective society groups. Here, music is considered both as a domain accompanying political phenomena as well as phenomena that are par excellence political. It is treated as an ideological instrument used by exponents of any ideology, who apply it not only for decorative purposes but first of all for the purpose of inciting the instinct of massive solidarity, enthusiasm, unanimous will and belief. The presentation is a polemic on the belief that prevails in the research on musicology that musical production is autonomous and it is considered exclusively as an act of free expression. 